\title{
Effect of Cyromazine Fed to Adults on Reproduction and Offspring Development in Housefly
}

\author{
Md. Jahangir Alam and Naoki Motoyama* \\ Laboratory of Pesticide Toxicology, Faculty of Horticulture, Chiba University, 648 Matsudo, Chiba 271-8510, \\ Japan
}

(Received November 15, 1999; Accepted February 14, 2000)

\begin{abstract}
The effect of cyromazine on reproduction, egg hatch and subsequent larval development in the housefly was studied by administering cyromazine in concentrations up to $1000 \mathrm{ppm}$ in adult drinking water. Larval survival was completely inhibited by the continuous feeding of 500 or 1000 ppm cyromazine to newly emerged adults and the effect was exerted predominantly through female. When the cyromazine feeding was limited to the first four days after emergence, the inhibitory effect on larval development was observed only at the first gonotrophic cycle. In any combinations of the cyromazine treatment, the egg production, egg hatch, pupa formation and adult emergence were not affected.
\end{abstract}

Key words: insect growth regulator, IGR, cyromazine, housefly, Musca domestica, effect on reproduction and development.

\section{INTRODUCTION}

Cyromazine is a commonly used insect growth regulator for the control of manure-breeding flies ${ }^{1)}$ and it is also well known to cause death in the immature stages by inducing abnormalities during larval and pupal development of the housefly, Musca domestica L., and other dipterous species. ${ }^{2-10}$ When cyromazine is applied to the larval stages of houseflies, early instar larvae are considerably more sensitive than later instar larvae. ${ }^{2}$ Although it has been suggested that cyromazine may disrupt the endocrine system, ${ }^{11)}$ the actual mode of action of cyromazine remains unclear. ${ }^{12-14)}$

Many conflicting reports of the effects of feeding cyromazine to adults of various species are found in the literature, particularly with respect to reproduction and offspring development. Some studies show that cyromazine has no effect on the adult stage in houseflies, face flies, Musca autumnalies De Geer ${ }^{15)}$ and sheep blowflies, Lucilia cuprina ${ }^{16)}$ Other studies claim that the compound has effects on at least one stage of egg production, egg hatch or egg to adult survival in various dipterous species. ${ }^{4,17-20)}$ The effect of cyromazine through adults appears dependent on the concentration tested. Hall and Foehse ${ }^{15)}$ found that cyromazine had no effect on the egg production and egg hatch when houseflies were fed

\footnotetext{
* To whom correspondence should be addressed.
}

up to $100 \mathrm{ppm}$. Pochon and Casida ${ }^{4)}$ found that cyromazine had no apparent effect on adult flies except at very high doses.

The previous studies did not examine the effect of feeding high concentration of cyromazine to housefly adult on the development of $F_{1}$ generation. In the present study the effect of cyromazine on reproduction and progeny development was investigated by feeding newly emerged parental male and female flies with various concentrations of cyromazine for various periods.

\section{MATERIALS AND METHODS}

\section{Chemical}

Technical grade (95.5\%) of cyromazine, $N$ cyclopropyl-1,3,5-triazine-2,4,6-triamine, and 14Ccyromazine [U-triazine ring-14C] with a specific activity of $16.7 \mu \mathrm{ci} / \mathrm{mg}$ and a radiochemical purity of $97.5 \%$ were the gifts from late Professor Dr. W. C. Dauterman of North Carolina State University, USA.

\section{Insects and Its Maintenance}

The CSMA strain of housefly used in the present study is an insecticide susceptible strain obtained from North Carolina State University, USA and maintained in our laboratory at $25 \pm 1^{\circ} \mathrm{C}$ and $\mathrm{RH} 75 \pm 5 \% .^{21)}$ The larvae were cultured on a mixture of the rat feed CE-2 (Nihon Clea Co.), wheat bran and water $(1: 1: 2.5 \mathrm{w} / \mathrm{w} / \mathrm{w})$. The adult flies were provided with powdered milk, sugar 
and water ad libitum.

\section{Experimental Procedures}

The flies were separated by sex right after their emergence and provided with various concentrations, i.e. 5 , 50,500 and $1000 \mathrm{ppm}$ of cyromazine in water prepared freshly for each set of experiment. The cyromazine and water were given through a piece of paper (Kim wipe ${ }^{\circledR}$ ) dipped in the solution in a small plastic cup $(4 \mathrm{~cm} \times 2 \mathrm{~cm}$, diameter $\times$ depth). Sugar and powdered milk were also supplied throughout the experimental period.

To ensure the cyromazine concentration orally administered to housefly adults $5 \mathrm{ml}$ of $1000 \mathrm{ppm}$ cyromazine solution was supplemented with $60,000 \mathrm{dpm} 14 \mathrm{C}$ cyromazine. Three $100 \mu 1$ aliquots of the cyromazine solution were sampled from the tip of $\mathrm{Kim}$ wipe ${ }^{\circledR}$ as well as from the solution in the plastic cup using a micropipette and the radioactivity was determined by LSC.

In this study three sets of experiments were designed in terms of cyromazine feeding period with various combinations of mating regime. In the first set of experiments the newly emerged flies were separated and fed with the above four different concentrations of cyromazine through drinking water continuously for four days along with the untreated (water only) control. After four days of treatment the cyromazine solutions were removed and replaced with water. Then the treated and untreated male and female flies were paired for thirteen different combinations with twelve replicates of each pair as shown in Table 1. The collection of eggs started 48 hours after making the mating groups. Since houseflies are known to lay 100 to 150 eggs at a time, and up to 600 or more eggs in less than a month at summer, ${ }^{22)}$ the eggs were collected in the present study five times from each pair once in every three days during the entire oviposition period in plastic cups containing a small amount of rearing medium. Then the collected eggs were transferred to another plastic cup $(11 \mathrm{~cm} \times 5.5 \mathrm{~cm}$, diameter $\times$ depth) containing a larger amount of the rearing medium sufficient for the subsequent development. The number of larvae was counted two days after the collection of eggs. The number of pupae and flies were also counted when they were produced.

In the second set of experiments the newly emerged male and female flies were separated and fed with cyromazine at concentrations of $500 \mathrm{ppm}$ and $1000 \mathrm{ppm}$ separately for 1 day only. The two concentrations were selected because the lower concentrations did not show any effect in the 4 day feeding experiment. The treated and untreated male and female flies were paired for seven different combinations as shown in Table 2. Eggs were collected and the observation of the subsequent development was made as described previously.

In the third set of experiments the newly emerged male and female flies were paired and fed with cyromazine at concentration of $5 \mathrm{ppm}, 50 \mathrm{ppm}, 500 \mathrm{ppm}$ and $1000 \mathrm{ppm}$ continuously throughout the oviposition period. The eggs were collected five times as before. The eggs from each pair were divided into two equal groups. One group was put on moistened filter paper to examine the percent hatching after 48 hours and another group was put in the rearing medium to examine the subsequent development.

In another test the eggs collected from untreated pairs were placed in a glass petridish $(9 \mathrm{~cm}$ diameter $)$ and covered with 500 or $1000 \mathrm{ppm}$ of cyromazine solution for 15 minutes at room temperature. The treated eggs were transferred, after removal of excess solution with a filter paper, to the larvae rearing medium as mentioned before and allowed to develop. A group of 25 eggs was used for each treatment with 12 replications and water served as control.

Data were analyzed by 1-way analysis of variance (ANOVA). Significant differences among means $(p<$ 0.01 ) were judged by least significant difference (LSD) test.

\section{RESULTS AND DISCUSSION}

\section{Effect of Four Day Feeding}

The radioactivity recovered from the Kim wipe ${ }^{\circledR}$ corresponded to $93.0 \pm 4.5 \%$ of that from the bottom solution in the plastic cup, verifying the cyromazine concentration administered to the housefly adults by this method.

The effect of feeding cyromazine for four days on egg production and the offspring development is summarized in Table 1. It is obvious that the cyromazine treatment produced little effect on number of eggs produced, $\%$ pupae formed and \% flies emerged regardless of mating combinations and cyromazine concentrations. In contrast, certain combinations of treatment produced significant larval mortality. When females fed with 500 or $1000 \mathrm{ppm}$ cyromazine were crossed with untreated males, larval survival was completely inhibited in the first gonotrophic cycle. The same results were also found when both sexes were treated with the two higher concentrations. However, this effect was limited only to the larvae obtained from the first gonotrophic cycle and no effect was shown in the subsequent gonotrophic cycles. In the second through fifth gonotrophic cycles the number of eggs produced, the \% larvae present, the \% pupae formed, and the $\%$ flies emerged from the treated crossings were not significantly different from the control.

Kotze $^{23)}$ also found somewhat similar results when cyromazine was administered to adult Lucilia cuprina. He found the egg production and egg hatch was not affected, while the larval survival was completely inhibited by $100 \mathrm{ppm}$ of cyromazine given in the drinking water. In our study the inhibition of larval develop- 


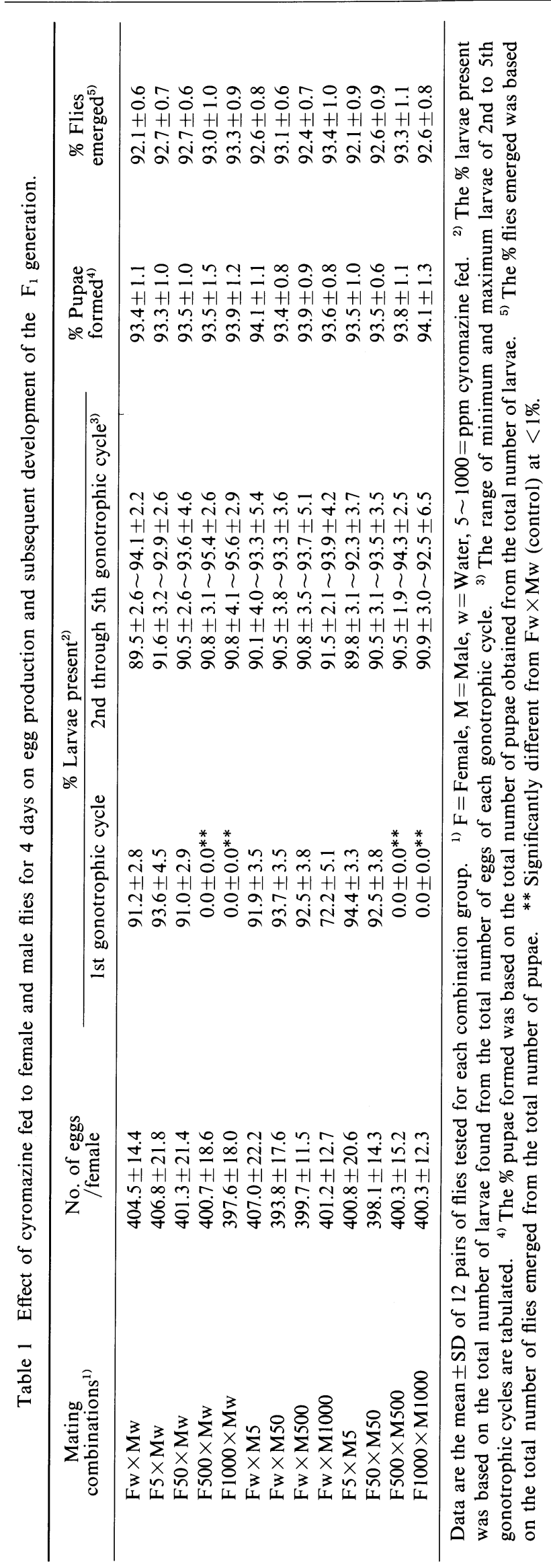

ment was found at higher concentrations only. The higher concentration required may reflect either a difference in the amount of cyromazine ingested by the two species or an intrinsic difference in the susceptibility to cyromazine between the two species. Although there is no information on the amount of cyromazine in the eggs, it is conjectured that a certain amount of cyromazine ingested through drinking water may have been transferred from the female flies to the eggs. The larval development can be inhibited only when the amount of cyromazine transferred to the eggs reached beyond a certain level. In support of this proposal Friedel and Mc-Donell, ${ }^{3)}$ working with the sheep blowfly, found that ca. $0.6 \%$ of the administered cyromazine was transferred to the eggs from the parental flies. Pyriproxyfen, a juvenile hormone mimic and insect growth regulator, is known to show a similar developmental inhibition in the $\mathrm{F}_{1}$ progeny when applied to the parent. Employing ${ }^{14} \mathrm{C}$ pyriproxyfen Langley et al. ${ }^{24)}$ demonstrated that it was stored in the female fat body, incorporated into vitellogenin, and transferred to the eggs in Rhodnius prolixus. In contrast to pyriproxyfen which is lipophilic in nature, cyromazine is a water soluble compound. The transportation mechanism of a water soluble compound such as cyromazine from oral ingestion to egg remains to be studied.

\section{Effect of One Day Feeding}

Results of feeding the high concentrations of cyromazine, i.e. 500 or $1000 \mathrm{ppm}$ for one day only are shown in Table 2. The results demonstrated that feeding these two concentrations for one day only is not enough to cause any effect on the reproduction and the development of the $F_{1}$ progeny. The cyromazine concentration transferred to the eggs was probably not enough to inhibit the larval development.

\section{Effect of Continuous Feeding}

Results of continuous feeding of cyromazine to newly emerged male and female flies are summarized in Table 3. In this experiment the lower concentrations, i.e. $5 \mathrm{ppm}$ and $50 \mathrm{ppm}$ were also included to examine the effect of longer feeding. The larval development was completely inhibited in the whole gonotrophic cycles when $500 \mathrm{ppm}$ and $1000 \mathrm{ppm}$ cyromazine were fed continuously throughout the entire period. Feeding the lower concentrations resulted in similar results to those of the control. Effect of cyromazine fed to male and female flies continuously on egg hatch is given in Table 4. No significant effect was observed on the hatching of eggs at any concentrations tested. Therefore, it is reasonable to conclude that the inhibition of larval development observed in Tables 1 and 3 was caused after hatching of the eggs, not due to the inhibition of egg hatch. Also, no significant effect by continuous feeding was observed for 


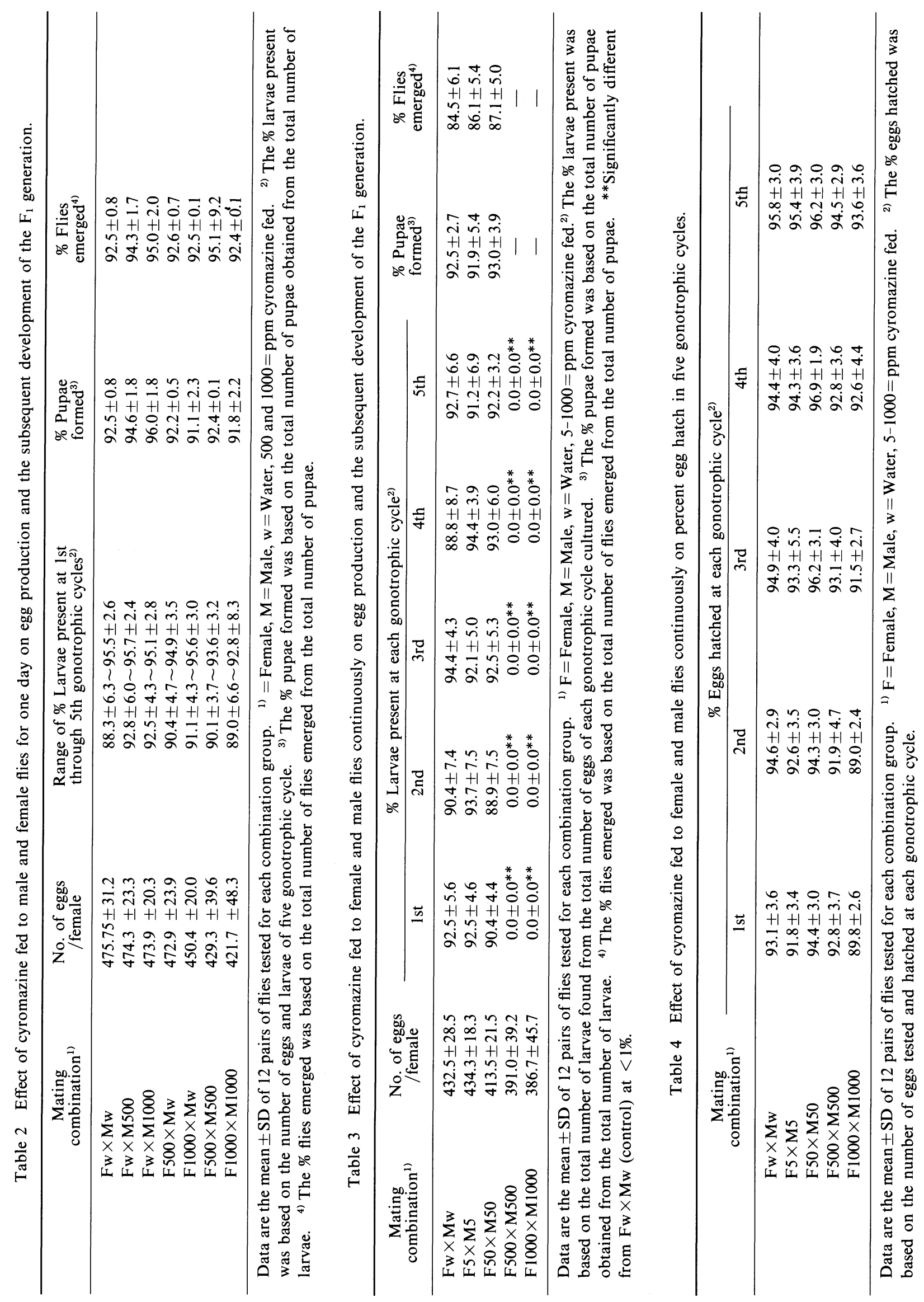


the production of eggs, \% pupae formed and \% flies emerged at any concentrations tested.

The fact that the continuous feeding of high concentrations inhibited the larval development in the present study is similar to the findings of Budia and Vinuela, ${ }^{17}$ who found that the larval development of the Mediterranean fruit fly, C. capitata, was hampered by continuous feeding of cyromazine in drinking water in a dose dependent manner and the complete inhibition was found at $10,000 \mu \mathrm{g} / \mathrm{ml}$.

The negligible effect of cyromazine feeding on the egg production and egg hatch in the present study is somewhat in agreement with studies by Borkovec et al., ${ }^{25)}$ who examined a series of diaminotriazines and reported that these compounds at doses affecting larval development did not interfere with oviposition and only slightly reduced egg hatch.

On the other hand, the results of our study differ markedly from those of Pochon and Casida, ${ }^{4)}$ who claimed that feeding $1000 \mathrm{ppm}$ cyromazine in drinking water could kill the adult houseflies within five days, although they did not elaborate exactly how water was provided. The study also showed that the hatchability could be decreased by feeding cyromazine at $300 \mathrm{ppm}$. The reason for the apparent conflicting results is not known.

\section{Effect of Egg Dipping}

The results of direct treatment of cyromazine on eggs are given in Table 5. No significant effect was observed at 500 and $1000 \mathrm{ppm}$ on hatching, larval survival, pupae formation and adult emergence. Grosscurt ${ }^{26)}$ also reported a similar finding with housefly eggs dipped in the $1000 \mathrm{ppm}$ diflubenzuron solution. The results suggest that the inhibition of larval development described above reflects the intrinsic effect of cyromazine incorporated into eggs before oviposition.

The fact that four day feeding effects were limited only to the 1st gonotrophical larvae while continuous feeding affected all five gonotrophic cycles suggests that cyrom-

Table 5 Effect of cyromazine directly applied to eggs on the subsequent development.

\begin{tabular}{lccl}
\hline $\begin{array}{l}\text { Cyromazine } \\
\text { concentration }\end{array}$ & $\begin{array}{c}\text { \% Larvae } \\
\text { present }^{1)}\end{array}$ & $\begin{array}{c}\text { \% Pupae } \\
\text { formed }^{2)}\end{array}$ & $\begin{array}{c}\text { \% Flies } \\
\text { emerged }^{3)}\end{array}$ \\
\hline Control & $91.3 \pm 5.3$ & $97.8 \pm 2.5$ & $95.6 \pm 4$ \\
$500 \mathrm{ppm}$ & $89.3 \pm 6.5$ & $99.2 \pm 2.0$ & $97.8 \pm 2.4$ \\
$1000 \mathrm{ppm}$ & $84.7 \pm 4.7$ & $97.7 \pm 2.6$ & $95.3 \pm 4.2$ \\
\hline
\end{tabular}

Data are the mean of 12 replications.

1) \% Larvae present was calculated on the basis of total number of eggs tested. 2) \% Pupae formed was calculated on the basis of total number of larvae tested. ${ }^{3)} \%$ Flies emerged was calculated on the basis of total number of pupae tested. azine not excreted may accumulate in the adult flies as will be shown in the subsequent paper employing ${ }^{14} \mathrm{C}$ cyromazine. ${ }^{27)} \quad$ Elucidation of how the compound given to the parental flies can affect the larval development in the next generation is an interesting subject for further studies.

\section{ACKNOWLEDGMENTS}

The authors are indebted to Dr. Randy Rose of North Carolina State University, USA and Dr. Takashi Mitsui of Tokyo University of Agriculture, Japan for critically reading the manuscript and making helpful suggestions.

\section{REFERENCES}

1) M.S. Mulla \& H. Axelrod: J. Econ. Entomol. 76, 515-519 (1983)

2) M.A. El-Oshard, N. Motoyama, P. B. Hughes \& W.C. Dauterman: J. Econ. Entomol. 78,1203-1207 (1985)

3) T. Friedel \& P. A. Mc-Donell: J. Econ. Entomol. 78, 868873 (1985)

4) J. M. Pochon \& J. E. Casida: Entomol. Exp. Appl. 34, 251256 (1983)

5) J.-F. Graf, R.F. Steiger, R.M. Immler, T. Friedel, F. Correa, H. Bouvard, M. von Orelli \& J. M. Somerville: Proceedings 10th International Congress World Association for the Advancement of Veterinary Parasitology, p. 74 (abstr.), 1983

6) R. J. Hart, W. A. Cavey, K. J. Ryan, M. B. Strong, B. Moore, P. L. Thomas, J. C. Boray \& M. von Orelli: Vet. J. 59, 104-109 (1982)

7) R.W. Miller, C. Corley, C. F. Cohen, W. E. Robbins \& E. P. Marks: Southwest. Entomol. 6, 272-278 (1981)

8) R. E. Williams \& J. G. Berry: Poult. Sci. 59, 2207-2212 (1980)

9) R.W. Miller \& C. Corley: Southwest. Entomol. 76, 515-519 (1980)

10) H. U. Brechbuhler, V. Laanio \& D. Berrer: U.S. Patent. 4 , 225-598 (1980)

11) T. Friedel, D. F. Hales \& D. Birch: Pestic. Biochem. Physiol. 31, 99-107 (1988)

12) K. C. Binnington: Tissue Cell 17, 131-140 (1985)

13) K. C. Binnington, A. Retnakaran, S. Stone \& P. Skelly: Pestic. Biochem. Physiol. 27, 201-201 (1987)

14) A. C. Kotze \& S. E. Reynolds: Bull. Entomol. Res. 83, 389393 (1993)

15) R. D. Hall \& M. C. Foehse: J. Econ. Entomol. 73, 564-569 (1980)

16) G. W. Levot \& E. Shipp: J. Aust. Entomol. Soc. 23, 85-89 (1984)

17) F. Budia \& E. Vinuela: J. Econ. Entomol. 89, 826-831 (1996)

18) D. S. Moreno, A. J. Martinez \& M. S. Riviello: J. Econ. Entomol. 87, 202-211 (1994)

19) J. D. Stark, R. I. Vargas, R. H. Messing \& M. Purcell: J. Econ. Entomol. 85, 1687-1694 (1992)

20) A. J. Martinez \& D. Moreno: J. Econ. Entomol. 84, 15401543 (1991)

21) E. Funaki \& N. Motoyama: J. Pesticide Sci. 11, 219 (1986)

22) R. E. Pfadt: "Fundamentals of Applied Entomology," McMillan Publishers, London, p. 622, 1989 
23) A. C. Kotze: J. Econ. Entomol. 85, 1614-1617 (1992)

24) P.A. Langley, V. Howl \& H. Oouchi: Entomol. Exp. Appl. 57, 271 (1990)

25) A.B. Borkovec, A. B. DeMilo \& R. L. Fye: J. Econ. Entomol. 65, 69-73 (1972)

26) A. C. Grosscurt: Pestic. Sci. 9, 373-386 (1978)

27) Md. J. Alam \& N. Motoyama: manuscript in preparation

\section{要 約}

イエバエの成虫に経口投与したシロマジンが生殖と 次世代の発育に及ぼす影響

Md. J. アラム，本山直樹 シロマジンを水に溶かして最大 1000 ppm までの濃度を
イエバエ成虫に経口投与した場合に，産卵数，孵化率，お よびその後の幼虫発育に及ぼす影響について調べた. 羽化 直後成虫に 500 または $1000 \mathrm{ppm}$ のシロマジンを連続的に 経口投与すると, 次世代の幼虫の発育は完全に阻害された が, この効果は雌成虫処理によってのみ発現した. シロマ ジン投与を羽化直後から 4 日間だけに限定した場合は, 次 世代幼虫の発育阻害効果は第 1 産卵期の卵から孵化した幼 虫にのみ見られた。成虫の交雑組み合わせやシロマジン投 与濃度にかかわらず，産卵数，卯孚化率，蛹化率，羽化率に は影響が見られなかった。 